
\title{
$\begin{array}{ll}\text { Research Square } & \begin{array}{l}\text { Preprints are preliminary reports that have not undergone peer review. } \\ \text { They should not be considered conclusive, used to inform clinical practice, } \\ \text { or referenced by the media as validated information. }\end{array}\end{array}$
}

\section{Effect of Dietary Amylose/amylopectin Ratio on Antioxidant Ability and Amino Acid Metabolism of Liver in Weaned Pigs Challenged with Lipopolysaccharide}

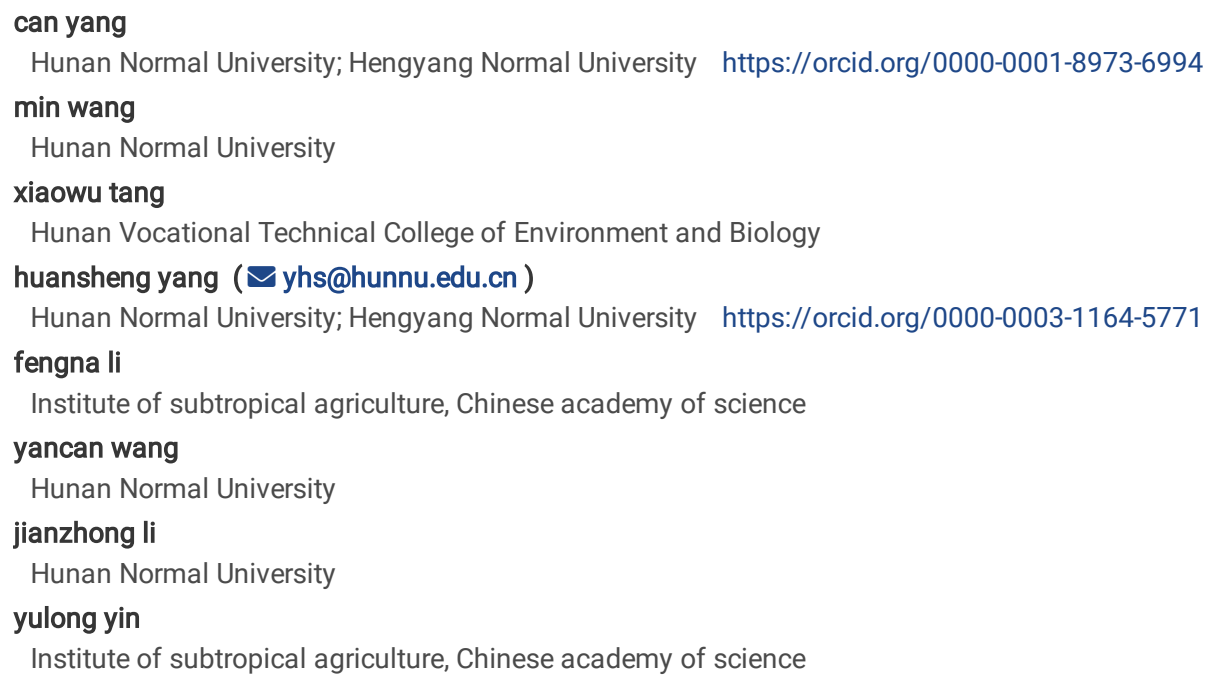




\section{Abstract}

Background: Antioxidant function could be regulated by resistant starch supplementation in rats with kidney disease. It is controversial whether antioxidant ability could be regulated by changing dietary amylose/amylopectin ratio (DAR) when weaned piglets under lipopolysaccharide (LPS) stress.

Methods: Sixty male weaned piglets (Duroc $\times$ Landrace $\times$ Yorkshire, 21 day old, $6.51 \pm 0.64 \mathrm{~kg}$ ) were allotted to 5 dietary treatments with 12 cages per treatment, and fed ad libitum with diets different in DAR $(0.00,0.20,0.40,0.60$ and 0.80$)$. Feed transformation happened at day 15 . On day $29,12 \mathrm{~h}$ before slaughter, pigs were intraperitoneal injected with $100 \mu \mathrm{g} / \mathrm{kg}$ body weight LPS or sterile saline.

Results: Results showed that LPS stress caused increase in serum urea nitrogen and glucose concentration $(P<0.05)$. Serum immunoglobulin $\mathrm{G}$ concentration increased after LPS stress in diet 0.80 but decreased in other groups $(P<0.05)$. Serum serine concentrations decreased after LPS stress in diets 0.20 and 0.80 but increased in other groups $(P<0.05)$. All tested hepatic amino acids (AA) increased after LPS stress $(P<0.05)$ but hepatic isoleucine, leucine, threonine, aspartate, serine, glutamate, glycine concentrations decreased after LPS stress in diet $0.20(P<0.05)$. Piglets supplemented diet with DAR 0.00 had highest superoxide dismutase (SOD1), nuclear factor 2 (Nrf2) and glutathione peroxidase 1 (GPX1) mRNA expression in liver ( $P<0.05)$. Total superoxide dismutase (T-SOD) activity of liver increased in diet 0.00 and 0.80 but decreased in diet $0.40(P<0.05)$. Total antioxidant capacity (T-AOC) activity of longissimus dorsi muscle (LM) increased in diets 0.20 and 0.80 but decreased in diet $0.40(P<0.05)$. Piglets in diet 0.20 had the highest hepatic glutathione peroxidase activity compared with groups $0.40,0.60,0.80(P<0.05)$. Mn concentration of $L M$ and hepatic Cu decreased after LPS stress in diet 0.20 but increased in diet $0.80(P<0.05)$. Piglets in diet 0.80 had the highest hepatic $\mathrm{Cu}, \mathrm{Fe}, \mathrm{Mn}, \mathrm{Zn}$ concentrations $(P<0.05)$. Cecal indol(e) concentration was higher in diet 0.00 than in diet $0.80(P<0.05)$.

Conclusions: Antioxidant ability could be improved by feeding diet with low or high amylose/amylopectin ratio when weaned piglets suffered LPS stress.

\section{Background}

Lipopolysaccharide (LPS) elicit a systemic inflammatory process through the release of proinflammatory mediators such as IL-1 $\beta$, IL-6 and TNF-a, as well as nitric oxide and reactive oxygen species (ROS) that are associated with oxidative stress [1]. Weaned piglets which have a weak mucosal barrier resistance to pathogens may increase the piglets' susceptibility to the infection of enterotoxigenic E.coli, which may even affect the intestinal disfunction [2], lead to oxidative stress in animals[3] , then result in hepatic damage ( $80 \mu \mathrm{g} / \mathrm{kg}$ body weight LPS)[4]. Lipopolysaccharide-induced hepatotoxicity remains a leading cause of death [5]. Liver plays an importeant physiological role in LPS detoxification, clearaning of endotoxin of intestinal derivation and exhibiting metabolic functions such as glycogenolysis and glycogen synthesis, protein metabolism [6].

The rate of starch digestion affects the level of digestion and absorption of nutrients, such as glucose, small peptides and amino acid [7]. Indigestible starch could be the source of nutrients for intestinal bacteria that convert the dietary fiber to short chain fatty acids (SCFA) [8]. SCFA are essential for the maintenance of the immunological self-tolerance and limitation of the inflammatory response [9]. Amelioration of oxidative stress, inflammation, restoration of Nrf2 activity was accompanied with consumption of 59\% high amylose maize resistant starch HAMRS2 in Chronic Kidney Disease (CKD) rats [10]. C57BL/6J mice supplemented with $20 \%$ HAMRS2 by weight showed $15-58 \%$ reduction in all measured liver and plasma amino acids, liver transcriptoics revealed pathways related to cell proliferation, differentiation, and growth were affected by HAMRS2 feeding[11].The beneficial effect of resistant starch (RS) could be driven by changes elicited at the hepatic which is associated with the oxidation reaction and hepatic inflammatory response in rats [12].

Starch is composed of amylose and amylopectin. Resistant starch content increased as amylose increased [7]. However, there is a dearth of information regarding the effect of dietary amylose/amylopectin ratio (DAR) on antioxidant activities of liver in piglets under LPS-challenge. Thus, this study was conducted to examine the antioxidant function of liver and its amino acid mechanism in weaned piglets under LPS stress.

\section{Methods}

Experimental procedure in this study was reviewed and approved by the Animal Care and Use Committee of Hunan Normal University.

\section{Animals and diets}

Sixty castrated male pigs (Landrace $\times$ Yorkshire) with an initial average body weight (BW) of $6.51 \pm 0.64$ kg were selected, blocked by BW and allotted to five dietary treatments with 12 cages per treatment and 1 pig per metabolic cage. The experimental diet was formulated on the basis of nutrient requirements established by the NRC [13] for $7 \otimes 11 \mathrm{~kg}$ pigs. The A, B, C, D, E diets differed only in DAR, $0.00,0.20,0.40,0.60$ or 0.80 respectively (Supplementary Table 1 ). Pigs were fed ad libitum. Water was provided ad libitum. On day 15 , feed was changed from phase $\nabla$ to phase $\nabla$. On day $29,12 \mathrm{~h}$ before slaughter, 6 pigs every treatment were challenged with lipopolysaccharides (LPS, from Escherichia coli 055:B5, Sigma Chemical Inc., St Louis, MO, USA, L2880) whereas an equivalent amount of sterile saline was administered to other 6 pigs. LPS was dissolved in sterile saline and administered intraperitoneal injection at 100 $\mu \mathrm{g} / \mathrm{kg}$ body weight. One pig from A, B, D, E died $11 \mathrm{~h}$ after LPS stress.

\section{Sample collection}

At day 15 before feed transition and day 28 , blood was collected from jugular vein and centrifuged at $3,000 \times \mathrm{g}, 4^{\circ} \mathrm{C}$ for $10 \mathrm{~min}$ to recover serum. Piglets were euthanized via an intravenous (jugular vein) injection of $40 \mathrm{mg} / \mathrm{kg}$ BW sodium pentobarbital solution. Then, tissues such as the middle right lobe of liver, 
dorsal muscles (approximately $2 \mathrm{~cm} \times 2 \mathrm{~cm}$ ) and chyme from cecal and colon were collected using the sterile scissors and tweezers. All of the samples were immediately stored at $-80^{\circ} \mathrm{C}$ for the further study.

\section{Analysis of serum biochemical variables}

The collected serum samples were thawed and centrifuged at $3000 \mathrm{rpm}$ for $10 \mathrm{~min}$ at $4^{\circ} \mathrm{C}$, and collected $200 \mu \mathrm{L}$ supernatant for measuring the concentration of total protein (TP), albumin (ALB), alanine transaminase (ALT), aspartate aminotransferase (AST), blood urea nitrogen (BUN), creatinine (CREA), glucose (GLU), triglyceride (TG), total cholesterol (CHOL), amylase (AMS), hepatic lipase (LIPC), immunoglobulin G and M (IGG, IGM) using commercial kits in accordance with manufacturer instructions (Jiancheng Bioengineering Institute, Nanjing, China) and where identified using a TBA-120FR Automatic Biochemistry Radiometer (Hitachi Co., Tokyo, Japan).

\section{Analysis of AA contents in serum, liver, and muscle}

The serum samples were thawed on $4^{\circ} \mathrm{C}$. Taking $600 \mu \mathrm{L}$ of serum and $8 \%$ sulfosalicylic acid in $1.5 \mathrm{ML}$ were mixed thoroughly, which stored at $4{ }^{\circ} \mathrm{C}$ for $12 \mathrm{~h}$. Then the mixed fluids were centrifuged at $10,000 \mathrm{rpm}$ and $4^{\circ} \mathrm{C}$ for $10 \mathrm{~min}$. The supernatant was filtered through a $0.22 \mu \mathrm{m}$ membrane and analyzed for $\mathrm{AA}$ using an AA analyzer (Hitachi L-8900, Japan). When AA contents in liver and muscle were tested, about $0.1 \mathrm{~g}$ ground freeze-dried sample was hydrolyzed in 10 $\mathrm{mL}$ of $6 \mathrm{~mol} / \mathrm{L} \mathrm{HCL}$ at $110^{\circ} \mathrm{C}$ for $22 \mathrm{~h}$. The solution was then adjusted to a volume of $100 \mathrm{~mL}$ and $1 \mathrm{~mL}$ of the settled solution was used for further analysis after 10-fold dilution. The diluent solution analyzed using an amino acid analyzer (L-8900, Hitachi, Japan) after filtered by a $0.22-\mu m$ membrane.

\section{Assay of hepatic, muscular antioxidant enzyme activities}

Hepatic and muscular tissue samples, were grounded in liquid nitrogen and homogenized in saline, and centrifuged at $3000 \times \mathrm{g}, 4^{\circ} \mathrm{C}$ for 10 min. The activities of malonaldehyde (MDA), superoxide dismutase (SOD) which includes cooper-zinc SOD (CuZn-SOD) and manganese SOD (Mn-SOD), glutathione peroxidase (GSH-PX/GPx), and total antioxidant capacity (T-AOC) were analyzed using commercial kits (Jiancheng Bioengineering Institue, Nanjing, China) according to the manufacturer's instructions.

\section{RNA Extraction and real-time quantitative PCR}

Total RNA was isolated from liver using RNAiso Plus (TaKaPa) and then reverse transcription reactions were performed using RT reagent kit (TaKaPa). All the procedures were carried out as described by the manufacturer's protocol. The quantity and quality of RNA were determined using NanoDrop ND-2000 spectrophotometer system (Thermo Fisher Scientific). Real-time RT-PCR primers were designed to assay genes related to antioxidant function (supplemented Table 2). 18S were used as reference gene. Real-time RT-PCR for target genes were performed on MyIQ instrument (Bio-Rad, Hercules, California) using SYBR Green quantitative PCR mix (TaKaRa).

\section{Analysis of mineral element contents in liver and muscle}

Macro and micro elements (Ca, S, Mg, Cu, Fe, Mn, Zn) were analyzed using analytical method as described earlier [14]. Briefly, liver and muscle samples (5.00 $\pm 0.20 \mathrm{~g}$ ) were weighed in triplicate and digested using a mixture acid (25 mL of HNO3: HCLO4 in volume ratio of 4:1) following heating ( $80 \mathrm{C}$ for $60 \mathrm{~min} ; 120 \mathrm{C}$ for $30 \mathrm{~min}$; and $180 \mathrm{C}$ for $30 \mathrm{~min}$ ). Samples were dried at $260 \mathrm{C}$ and redissolved in $5 \mathrm{~mL}$ of $1 \% \mathrm{HNO}$. Solution was then transferred to a $25-\mathrm{mL}$ volumetric flask and filled with $1 \%$ HNO3. Finally, target elements (Cu, Fe, Mn and Zn) in samples were determined on ICP-OES (Varian 720ES Agilent, Santa Clara, CA, USA) for confirmation with standard references.

\section{Analysis of indole and skatole contents in chyme}

Indole and skatole (3-methylindole) of luminal contents in cecal and colon were analysed as described previously on high-performance liquid chromatography (HPLC, Agilent 1260, Agilent Technologies Inc., USA) [15]. Briefly, luminal contents in cecal and colon were weighted (1.000 g) and extracted by $8 \mathrm{~mL} 0.4$ $\mathrm{mol} / \mathrm{L}$ perchloric acid overnight. Then the suspension was acquired by centrifuge $10 \mathrm{~min}$ at $8000 \mathrm{r} / \mathrm{min}$ at $4^{\circ} \mathrm{C} .1 \mathrm{~mL}$ of supernatant was being homogenate with $1 \mathrm{~mL}$ sodium hydroxide (2 mol/l, $\mathrm{pH} 10.6)$-saturated sodium bicarbonate buffer solution, then added $1 \mathrm{ml}$ of dansulfonyl chloride (10 mg/ml acetone solution). The solution incubated at $40^{\circ} \mathrm{C}$ water in a dark place for $30 \mathrm{~min}$, and then add $1 \mathrm{~mL} 5 \%$ of ammonia water. Finally, 3 mL of anhydrous ether was used to extract the solution. The anhydrous ether layer was dried and dissolved in $1 \mathrm{~mL}$ methanol, filtered by $0.22 \mu \mathrm{m}$ syringe filter membrane and analyzed on the machine.

\section{Statistics analysis}

Gene expression data from replicate measurement within the same RNA extraction were averaged and analyzed using Livak's (2001) [16] method to measure the difference between the five DAR diets. All data were analyzed using the General Linear Model (GLM) procedure of SAS 8.0. Duncan differences were determined to compare differences among the groups. The variability in data was showed as standard error of mean $(S E M)$, and the $P<0.05$ was considered statistical significance. 


\section{Results}

\section{Serum biochemical variables and free amino acids at day 15}

Serum TP, ALB, ALT, AST, BUN, TG, AMS at day 15 were not affected by DAR (Table 1). Serum CREA was higher in diet 0.80 than in other groups $(P<0.05)$. Serum GLU was higher in group 0.20 than in groups 0.00 and $0.40(P<0.05)$, with no significant difference compared with groups 0.60 and $0.80(P>0.05)$. Serum $\mathrm{CHOL}$ was higher in groups 0.00 and 0.60 than in group $0.40(P<0.05)$.

Serum essential amino acid at day 15 was not affected by DAR $(P>0.05)$ except that groups 0.00 had the lowest serum arginine compared with groups 0.40 and $0.60(P<0.05)$ (Table 2). Serum non-essential amino acid was not affected by DAR except alanine, aspartate, proline, sarcosine, citrulline, anserine, carnosine, $\mathrm{a}$-aminoadipic acid, $\mathrm{a}$-amino-n-butyric acid, $\mathrm{y}$-aminobutyric acid and ethanolamine $(P>0.05)$. Serum proline was lower but anserine was higher in diet 0.00 than in other groups $(P<0.05)$. Serum aspartate and ethanolamine were higher in diets 0.20 than in diets 0.60 and $0.80(P<0.05)$. Serum sarcosine and carnosine were higher in diet 0.40 than in groups $0.00,0.20$ and $0.80(P<0.05)$. Serum $y$-aminobutyric acid was higher in diet 0.60 than in other groups $(P$ $<0.05)$. Serum alanine, citrulline and a-amino-n-butyric acid was higher in diet 0.80 than in diets $0.00,0.40(P<0.05)$. Serum a-aminoadipic acid was higher in diet 0.80 than in diets $0.20,0.40,0.60(P<0.05)$.

\section{Absolute and relative organ weight}

Absolute weight of organ was not affected by DAR (Table 3, P>0.05). LPS stress caused increase in absolute weight of liver and decrease in large intestine $(P<0.05)$. Absolute weight of kidney tended to increase after LPS stress $(P=0.051)$. Relative organ weight such as stomach, liver, spleen, kidney and length of small intestine were not affected by DAR ( $P>0.05)$. Relative weight of small intestine increased after LPS stress in diet 0.20 and 0.80 but decreased in other groups $(P<0.05)$. Relative weight of large intestine decreased after LPS stress $(P<0.05)$.

\section{Serum biochemical variables and free amino acids at day 29}

Serum TP, ALB, ALT, AST, BUN, CREA, GLU, CHOL and IGM was not affect by DAR (Table 4). Serum TG was lower in diet 0.40 than in groups 0.60 and $0.80(P<$ 0.05). Serum AMS was lower in diets 0.00 than in diet 0.20 , which lower than in diet $0.60(P<0.05)$. Serum IGG was lower in diet 0.00 than in diet 0.20 , which was lower than in diet 0.40 and diet 0.80 had the highest IGG concentration $(P<0.05)$. Serum ALT, CREA, AMS and LIPC decreased but serum GLU, BUN, AST increased after LPS stress $(P<0.05)$. Serum IGG increased after LPS stress in diets 0.80 but decreased after LPS stress in other groups $(P<0.05)$.

Serum essential amino acid was not affected by DAR $(P>0.05)$ except that diet 0.80 had the highest serum arginine, higher than in groups $0.00,0.20$ and 0.40 (Table 5, $P<0.05)$. Serum non-essential amino acid was not affected by DAR $(P>0.05)$ except proline, sarcosine, citrulline, anserine, hydroxylysine, $\beta$ aminoisobutyric acid and hydroxy-L-proline $(P<0.05)$. Serum proline was higher in diet 0.60 than in $0.80,0.40$ and $0.00(P<0.05)$. Piglets consumping diet with DAR 0.80 had the highest concentration of serum sarcosine, citrulline, anserine, hydroxylysine, b-aminoisobutyric acid. Serum hydroxy-L-proline was higher in diets 0.20 and 0.60 than in diet $0.00(P<0.05)$. Serum essential amino acid decreased after LPS stress $(P<0.05)$ except histidine which was not affected by LPS stress $(P>0.05)$. Serum tyrosine, alanine, aspartate, glutamate, cysteine, proline, urea, citrulline, carnosine, ornithine, a-Amino-n-butyric acid, Hydroxy-L-proline were affected by LPS stress $(P<0.05)$. There is significant effect of interaction between AAR and LPS on serum methionine, phenylalanine, valine, arginine, tyrosine, serine, hydroxy-L-proline $(P<0.05)$. Serum phenylalanine increased after LPS stress in diet 0.40 but decreased in other groups $(P<$ 0.05). Serum valine decreased after LPS stress but maintained stable in other groups $(P<0.05)$. Serum arginine and tyrosine maintain stable in diet 0.00 after LPS stress but decreased in other groups $(P<0.05)$. Serum serine decreased after LPS stress in diets 0.20 and 0.80 but increased in other groups $(P<0.05)$. Serum hydorxy-L-proline increased in diets 0.00 and 0.60 after LPS stress but maintained stable in other groups $(P<0.05)$.

\section{Amino acid contents in liver and dorsal muscle}

Amino acid concentration of longissimus dorsi muscle was not affected by DAR and LPS stress (Table $6, P>0.05$ ). Hepatic cysteine was lower in diet 0.80 than in diets 0.00 and $0.20(P<0.05)$. There was significant effect of interaction between DAR and LPS stress on hepatic isoleucine, leucine, phenylalanine, threonine, aspartate, serine, glutamate, glycine concentrations $(P<0.05)$. All these amino acids of liver decreased after LPS stress in diet 0.20 but increased in other groups $(P<0.05)$.

\section{Antioxidant function of liver and muscle}

Concentration of MDA in muscle was not affected by DAR or LPS stress (Table 7, $P>0.05$ ). Activity of T-AOC in muscle was higher in diets 0.60 and 0.80 than in diets $0.00,0.20$ and $0.40(P<0.05)$, it decreased after LPS stress in diet 0.40 but increased in other groups $(P<0.05)$. Activity of T-AOC in liver was not affected by DAR or LPS stress $(P>0.05)$. Activities of GSH-PX was higher in diet 0.20 than in diets $0.40,0.60$ and $0.80(P<0.05)$, they increased after LPS stress $(P<0.05)$. Concentration of MDA was higher in diet 0.20 than in diets $0.00,0.40$ and $0.80(P<0.05)$. Hepatic T-SOD activity decreased after LPS stress in diet 0.40 but increased in diets 0.00 and $0.80(P<0.05)$. Activity of Cu-SOD was lower in diet 0.20 than in other groups $(P<0.05)$.

Gene related to antioxidant function such as SOD1, Nrf2, GPX1 mRNA expression was affected by DARA, which was higher in group 0.00 than in other groups $(P<0.05)$. LPS stress caused increased in abundance of gene SOD1 and GPX1 $(P<0.05)$. mRNA expression of SOD1 and Nrf2 decreased after LPS stress in 
diets 0.40 and 0.60 but increased in other groups $(P<0.05)$. Gene of GCLC expression decreased after LPS stress in diets $0.40,0.60,0.80$ but increased after LPS stress in diets 0.00 and $0.20(P<0.05)$.

\section{Mineral element contents in liver and muscle}

All of the tested mineral element in muscle was not affected by LPS stress (Table $8, P>0.05$ ). Mineral element concentrations such as Ca, Fe, Mg, S were not affected by DAR $(P>0.05)$. Muscle from piglets in diet 0.80 had the lowest $\mathrm{Cu}$ and $\mathrm{Zn}$ concentrations compared with other groups $(P<0.05)$. Diet 0.80 tended to have the lowest Mn in muscle $(P=0.052)$. Mn of muscle decreased after LPS stress in diets 0.20 and 0.60 but increased in other groups $(P<0.05)$.

\section{Indole and skatole contents in chyme}

Cecal indole concentration was higher in diet 0.00 than in diet $0.80(P<0.05)$, it was not affected by LPS stress $(P>0.05)$. Cecal skatole and colonic indole were not affected by DAR or LPS stress $(P>0.05)$. Diet 0.00 had the lowest colonic skatole than in diet $0.40,0.60$ and $0.80(P<0.05)$. Skatole in colon increased after LPS stress in diets 0.40 and 0.80 but decreased in other groups $(P<0.05)$.

\section{Discussion}

Oxidative stress is condition in which production of reactive oxygen species (ROS) exceeds the capacity of the antioxidant system, it caused tissue damage and dysfunction. Generally, the ROS including MDA which is a metabolite produced after lipid peroxidation [17]. Increases in indices of lipid peroxidation in rat were accompanied by reduced activity levels of liver GPX and CuZn-SOD. Serum AST activity is a key biochemical markers of liver health and function. LPS stress caused elevation of serum AST level, which could be considered to be a sensitive indicator of liver injury [18]. In order to overcome LPS stress, antioxidant activity represented by GSH-PX activity and gene expression of GPX1 and SOD1 increased in liver of weaned piglets. The SOD enzymes keep the intracellular steady-state concentration of $02^{-}$low, while GPX remove the $\mathrm{H} 2 \mathrm{O} 2$ generated from the dismutation [19]. Our results are inconsistent with [20], who summarized that the SOD1 and GPX1 activity of mice will down-regulate, and the expression levels of GCLCand $\mathrm{Nrf} 2 \mathrm{were}$ significantly decreased $2 \mathrm{~h}$ after $8 \mathrm{mg} / \mathrm{kg}$ LPS challenge [21]. This has to do with our sampling time. We sample 12h after LPS challenge, 12-hour recovery time was more effective in fully restored piglet liver function than 2 hours. 15 day after LPS stress, proteins involved in inflammatory response, oxidation-redox processes and defense reactions were enriched in a phagosome pathway in liver of weaning piglet [4].

Weaned piglets supplemented diet with DAR 0.40 showed weak response to LPS stress, T-SOD of liver and T-AOC concentration in muscle decreased after LPS stress in diet with DAR 0.40 but increased in group 0.80 . Addition of resistant starch (RS) in the high fat diet will significantly increase the glutamate-cysteine ligase catalytic subunit $(G C L C)$ gene expression, which involved in celluar antioxidant response to ROS, and then perform the better efficiently in suppressing stress by elevating T-AOC and GSH-PX levels [22]. Copper, zinc-superoxide dismutase (SOD1) is a major intracellular antioxidant enzyme in mammals, its activity is important for the catalysis of LPS-induced hepatic protein nitration in mice[23]. Eukaryotic cells have two forms of SOD: one is founded in the mitochondrial matrix (Mn-SOD) and another is founded in the cytosol (CuZn-SOD) [24]. Relative organ weight of intestine increased after LPS stress in diet 0.80 , which indicates an increase in digestion and absorption. As a result of the hypertrophy of the cecal wall and of the cecal acidification, raw potato starch (RS2) fermentation increases intestinal absorption of $\mathrm{Ca}, \mathrm{Mg}, \mathrm{Fe}, \mathrm{Zn}$ and $\mathrm{Cu}$ [25]. Hepatic Cu concentration and muscular Mn increased after LPS stress in diet 0.80 but not in other groups. Accordingly, SOD1 mRNA expression decreased after LPS stress in diet 0.40 but increased in diet 0.80 . Indoxyl sulfate and Pcresole sulfate are among the major microbial derived pro-inflammatory and pro-oxidant uremic toxins. Production of indoxyl sulfate and P-cresole sulfate increased at higher $\mathrm{pH}$ [26]. By increasing production of SCFA, production of indoles of cecum decreased as a result of lowering the luminal $\mathrm{pH}$ in diet 0.80 . Serum a-Amino-n-butyric acid was the highest in diet 0.80 . Serum IGG decreased after LPS stress in other groups but increased in diet 0.80 . Increase of immunoglobulin increases the body's resistance to inflammation, which could be benefit to antioxidant ability as oxidative stress and inflammation are inseparable linked as each trigger and amplifies the other.

Studies assumed that an increase RS would decrease the abundance of protein fermentation products [27, 28]. After $24 \mathrm{~h}$ incubation of cecal and colonic digesta, production of ammonia-nitrogen and branched-chain fatty acids, which indicated protein fermentation, decreased when the corn resistant starch levels increased [27]. BCFA including isobutyrate and isovalerate concentrations significantly increased when the DAR was 0.20 , suggesting that the DAR changed fermentation pattern and increased protein fermentation (data not shown). Protein fermentation products have been associated with toxic and proinflammatory impacts on the intestinal epithelium [29], which resulted in highest hepatic MDA concentration in diet 0.20 . Normally, liver protein synthesis increased when animals undergoing immune challenge. Due to higher protein fermentation, hepatic isoleucine, leucine decreased after LPS stress in diet 0.20 because BCFA such as iso-butyrate, 2-methyl-butyrate, iso-valerate originate from deamination of valine, isoleucine and leucine. We should notice that serum serine decreased after LPS stress in diet 0.20 and 0.80 but increased in other groups. Serine participates in a metabolic network that interlinks the folate cycle and methionine cycle to support cell proliferation [30]. Serine is a precursor of glycine and cysteine that constitutes components of the cellular antioxidant glutathione (GSH). On the other side, hepatic amino acids such as phenylalanine, threonine, aspartate, serine, glutamate, glycine could be mobilized to build defences battle with MDA. Increase in the quantity of amino acid which enter the portal vein could be useful in improving tissue protein synthesis[31] . Higher hepatic cysteine in group 0.20 suggests that glutathione is in the process of synthesis in this group. Finally, it (diet 0.20 ) had highest GSH-PX activity in liver than in other groups. Gene expression of Nrf2 and glutamate-cysteine ligase catalytic subunit (GCLC) of liver increased after LPS stress in diet 0.00 and 0.20 but decreased in other groups. Nrf2 is the master regulator of close to 250 genes encoding antioxidant and cytoprotective enzymes and proteins [32].

\section{Conclusions}


In conclude, antioxidant ability of liver was affected by dietary amylose/amylopectin ratio when weaned piglets suffered LPS stress. More hepatic amino acids would be mobilized to synthesis glutathione peroxidase to defend LPS stress when weaned piglets supplemented diet with DAR 0.20. More Cu and Zn deposited in the liver and more Mn deposited in the muscle, and then antioxidant ability of liver and muscle increased after LPS stress when weaned piglets consuming diet with DAR0.80. Dietary amylose/amylopectin ratio (DAR) for most of the diet used in swine production is 0.40 . Our study confirmed that diet with DAR 0.40 had disadvantageous when weaned piglets had experienced feed transition and then LPS stress. Supplemented amylose or amylopectin would be better for piglets under LPS stress through improving antioxidant function or amino acid metabolism.

\section{Declarations}

\section{Ethics approval and consent to participate}

Experimental procedure in this study was reviewed and approved by the Animal Care and Use Committee of the Hunan international joint laboratory of animal intestinal ecology and health, Hunan Normal University.

\section{Consent for publication}

Not applicable

\section{Availability of data and material}

The datasets used and/or analysed during the current study are available from the corresponding author on reasonable request.

\section{Competing interests}

The authors declare that they have no competing interests.

\section{Funding}

This research was supported by Research foundation of the Education of Hunan Province (18B374), China postdoctoral science foundation funded project (No.2016M600630) and Applied Basic Research Programs of Science and Technology Foundation of HuNan Province (No. 2016JC2034).

\section{Authors' contributions}

Yin Yulong and Yang Huansheng organized the experiment and gave some advice on experiment idea. Yang Can conducted the experiment and was a major contributor in writing the manuscript. Yang Can, Wang Min, Tang Xiaowu and Wang Yancan conducted the experimental analysis. Li Fengna and Li Jianzhong reviewed the manuscript and gave some advice on experiment idea. All authors read and approved the final manuscript

\section{Acknowledgements}

Not applicable

\section{Authorship}

Can Yang, post doctor in Hunan Normal University, tutor is Dr. Yulong Yin.

\section{References}

1. Qiao Y, Bai XF, Du YG: Chitosan oligosaccharides protect mice from LPS challenge by attenuation of inflammation and oxidative stress. International Immunopharmacology 2011, 11:121-127.

2. Xiao D, Wang Y, Liu G, He J, Qiu W, Hu X, Feng Z, Ran M, M. NC, Sung WK: Effects of Chitosan on Intestinal Inflammation in Weaned Pigs Challenged by Enterotoxigenic Escherichia coli. PLoS ONE,9,8(2014-8-4) 2014, 9:e104192.

3. Yuan S, Chen D, Zhang K, Yu B: Effects of Oxidative Stress on Growth Performance, Nutrient Digestibilities and Activities of Antioxidative Enzymes of Weanling Pigs. Asian-australasian journal of animal sciences 2007, 20:1600-1605.

4. Xia B, Meng Q, Feng X, Tang X, Jia Z: Probing the molecular regulation of lipopolysaccharide stress in piglet liver by comparative proteomics analysis. Electrophoresis the Official Journal of the International Electrophoresis Society 2018.

5. Rana M, Reddy S, Maurya P, Singh V, Chaturvedi S, Kaur K, Agarwal H, Ahmad H, Naqvi A, Dwivedi A: Turmerone enriched standardized Curcuma longa extract alleviates LPS induced inflammation and cytokine production by regulating TLR4-IRAK1-ROS-MAPK-NFKB axis. Journal of Functional Foods 2015, 16:152-163. 
6. Jia A, Feng J, Zhang M, Chang Y, Li Z, Hu C, Zhen L, Zhang S, Peng Q: Effects of immunological challenge induced by lipopolysaccharide on skeletal muscle fiber type conversion of piglets. Journal of Animal Science 2015, 93:5194-5203.

7. Yin F, Yin Y, Zhang Z, Xie M, Li T: Digestion rate of dietary starch affects the systemic circulation of lipid profiles and lipid metabolism-related gene expression in weaned pigs. British Journal of Nutrition 2011, 106:369-377.

8. Yang C, He J, Yu B, Yu J, Mao XB, Chen DW, Yin YL: The effect of dietary amylose/amylopectin ratio on serum and hepatic lipid content and its molecular mechanisms in growing-finishing pigs. Journal of Animal Physiology and Animal Nutrition 2018, 102:1657-1665.

9. Smith PM, Howitt MR, Panikov N, Michaud M, Gallini CA, Bohlooly-Y M, Glickman JN, Garrett WS: The Microbial Metabolites, Short-Chain Fatty Acids, Regulate Colonic Treg Cell Homeostasis. Science 2013, 341:569-573.

10. Vaziri ND, Liu SM, Lau WL, Khazaeli M, Nazertehrani S, Farzaneh SH, Kieffer DA, Adams SH, Martin RJ: High amylose resistant starch diet ameliorates oxidative stress, inflammation, and progression of chronic kidney disease. PLoS One 2014, 9:e114881.

11. Kieffer DA, Piccolo BD, Marco ML, Kim EB, Goodson ML, Keenan MJ, Dunn TN, Knudsen KEB, Martin RJ, Adams SH: Mice Fed a High-Fat Diet Supplemented with Resistant Starch Display Marked Shifts in the Liver Metabolome Concurrent with Altered Gut Bacteria. Journal of Nutrition 2016, 146:2476-2490.

12. Polakof S, Díaz-Rubio ME, Dardevet D, Martin JFO, Pujos-Guillot E, Scalbert A, Sebedio JL, Mazur A, Comte B: Resistant starch intake partly restores metabolic and inflammatory alterations in the liver of high-fat-diet-fed rats. Journal of Nutritional Biochemistry 2013, 24:1920-1930.

13. Council. NR: Nutrient Requirements of Swine. Washington, DC: National Academy Press 2012.

14. Zhang $Y$, Wan D, Zhou X, Long C, Wu X, Li L, He L, Huang P, Chen S, Tan B: Diumal variations in iron concentrations and expression of genes involved in iron absorption and metabolism in pigs. Biochemical \& Biophysical Research Communications 2017, 490:1210-1214.

15. Xu L, Geng M, Zhang L, Yuan H, Kong X, Wang J: Determination of biomines in colonic contents of piglets by pre-column column derivatization RP-HPLC. Acta Nutrimenta Sinica 2014, 36:78-83.

16. Livak KJ, Schmittgen TD: Analysis of relative gene expression data using real-time quantitative PCR and the 2(-Delta Delta C(T)) Method. Methods 2001, 25:402-408.

17. Li Y, Li L, Li J, Zhang L, Gao F, Zhou G: Effects of dietary supplementation with ferulic acid or vitamin E individually or in combination on meat quality and antioxidant capacity of finishing pigs. Asian-Australasian journal of animal sciences 2015, 28:374.

18. Jing M, Munyaka P, Tactacan G, Rodriguez-Lecompte J, O K, House J: Performance, serum biochemical responses, and gene expression of intestinal folate transporters of young and older laying hens in response to dietary folic acid supplementation and challenge with Escherichia coli lipopolysaccharide. Poult Sci 2014, 93:122-131.

19. Polavarapu R, Spitz DR, Sim JE, Follansbee MH, Oberley LW, Rahemtulla A, Nanji AA: Increased lipid peroxidation and impaired antioxidant enzyme function is associated with pathological liver injury in experimental alcoholic liver disease in rats fed diets high in corn oil and fish oil. Hepatology 1998 , 27:1317-1323.

20. Zhu JH, Lei XG: Lipopolysaccharide-induced hepatic oxidative injury is not potentiated by knockout of GPX1 and SOD1 in mice. Biochem Biophys Res Commun 2011, 404:559-563

21. Dong, Lile, Han, Xu, Tao, Xufeng, Lina, Youwei, Fang, Linlin: Protection by the Total Flavonoids from Rosa laevigata Michx Fruit against Lipopolysaccharide-Induced Liver Injury in Mice via Modulation of FXR Signaling. Foods 2018, 7:88.

22. Si X, Strappe P, Blanchard C, Zhou Z: Enhanced anti-obesity effects of complex of resistant starch and chitosan in high fat diet fed rats. Carbohydrate Polymers 2017, 157:834-841.

23. Zhu JH, Zhang X, Roneker CA, Mcclung JP, Zhang S, Thannhauser TW, Ripoll DR, Sun Q, Lei XG: Role of Copper,Zinc-Superoxide Dismutase in Catalyzing Nitrotyrosine Formation in Murine Liver. Free Radical Biology and Medicine 2008, 45:611-618.

24. Nanji AA, Griniuviene B, Sadrzadeh SM, Levitsky S, McCully JD: Effect of type of dietary fat and ethanol on antioxidant enzyme mRNA induction in rat liver. J Lipid Res 1995, 36:736-744.

25. Lopez H, Levrat-Verny M, Coudray C, Besson C, Krespine V, Messager V, Demigne C, Remesy C: Class 2 resistant starches lower plasma and liver lipids and improve mineral retention in rats. Journal of Nutrition 2001, 131:1283-1289.

26. Smith囚EA, Macfarlane G: Formation of Phenolic and Indolic Compounds by Anaerobic Bacteria in the Human Large Intestine. Microbial Ecology 1997, 33:180-188.

27. He X, Sun W, Ge T, Mu C, Zhu W: An increase in corn resistant starch decreases protein fermentation and modulates gut microbiota during in vitro cultivation of pig large intestinal inocula. Animal Nutrition (English edition) 2017, 000:219-224.

28. Metzler-Zebeli B, Hooda S, Pieper R, Zijistra R, van Kessel A, Mosenthin R, Ganzle M: Nonstarch Polysaccharides Modulate Bacterial Microbiota, Pathways for Butyrate Production, and abundance of Pathogenic Escherichia coli in the Pig Gastrointestinal Tract. Applied \& Environmental Microbiology 2010, 76:3692-3701.

29. Blaut M, Clavel T: Metabolic diversity of the intestinal microbiota: implications for health and disease. Journal of Nutrition 2007, 137:751S.

30. Ducker G, Rabinowitz J: One-Carbon Metabolism in Health and Disease. Cell Metabolism 2016, 25:27.

31. Liu G, Yu L, Yordan M, Ren W, Ni H, Naif AD, Veeramuthu D, Yin Y: Dietary Saccharomyces cerevisiae Cell Wall Extract Supplementation Alleviates Oxidative Stress and Modulates Serum Amino Acids Profiles in Weaned Piglets. Oxidative Medicine and Cellular Longevity 2017, $2017: 1-7$.

32. Kim HJ, Vaziri ND: Contribution of impaired Nrf2-Keap1 pathway to oxidative stress and inflammation in chronic renal failure. American Journal of Physiology Renal Physiology 2010, 298:662-671.

Page 7/16 
Tables

Table 1

Effects of dietary amylose/amylopectin ratio on serum biochemical index on day 15 in weaned piglets

\begin{tabular}{|c|c|c|c|c|c|c|c|}
\hline Item & 0.00 & 0.20 & 0.40 & 0.60 & 0.80 & SEM & $P$ value \\
\hline $\mathrm{TP}, \mathrm{g} / \mathrm{L}$ & 47.22 & 49.51 & 45.60 & 45.97 & 45.12 & 0.68 & 0.260 \\
\hline ALB, $g / L$ & 25.59 & 26.73 & 24.53 & 26.29 & 25.70 & 0.52 & 0.725 \\
\hline ALT, U/L & 34.48 & 36.59 & 42.79 & 44.38 & 39.13 & 1.58 & 0.264 \\
\hline AST, U/L & 55.73 & 62.25 & 55.67 & 53.67 & 51.00 & 2.50 & 0.693 \\
\hline AST/ALT & 4.54 & 5.13 & 4.83 & 4.48 & 4.73 & 0.22 & 0.895 \\
\hline $\mathrm{BUN}, \mathrm{mmol} / \mathrm{L}$ & 60.00 & 63.92 & 66.92 & 63.75 & 63.00 & 1.60 & 0.762 \\
\hline CREA, umol/L & $4.68^{\mathrm{B}}$ & $4.73^{\mathrm{B}}$ & $4.53^{\mathrm{B}}$ & $4.58^{\mathrm{B}}$ & $5.32^{\mathrm{A}}$ & 0.08 & 0.027 \\
\hline $\mathrm{GLU}, \mathrm{mmol} / \mathrm{L}$ & $0.45^{\mathrm{B}}$ & $0.60^{\mathrm{A}}$ & $0.40^{\mathrm{B}}$ & $0.47^{\mathrm{AB}}$ & $0.53^{A B}$ & 0.02 & 0.023 \\
\hline $\mathrm{TG}, \mathrm{mmol} / \mathrm{L}$ & 1.87 & 2.07 & 1.87 & 2.02 & 2.05 & 0.05 & 0.405 \\
\hline $\mathrm{CHOL}, \mathrm{mmol} / \mathrm{L}$ & $2642^{\mathrm{A}}$ & $2230^{A B}$ & $2022^{\mathrm{B}}$ & $2493^{A}$ & $2226^{A B}$ & 63.79 & 0.031 \\
\hline AMS, U/L & 4.22 & 4.56 & 3.93 & 4.55 & 4.13 & 0.12 & 0.421 \\
\hline
\end{tabular}


Table 2

Effects of DAR on serum free AA concentration on day 15 in weaned piglets

\begin{tabular}{|c|c|c|c|c|c|c|c|}
\hline Item & 0.00 & 0.20 & 0.40 & 0.60 & 0.80 & SEM & $P$ value \\
\hline \multicolumn{8}{|l|}{ Essential amino acid } \\
\hline Lysine & 418.65 & 488.86 & 441.79 & 413.45 & 432.75 & 19.48 & 0.752 \\
\hline Methionine & 118.90 & 131.43 & 122.62 & 134.92 & 147.40 & 4.92 & 0.403 \\
\hline Histidine & 137.54 & 154.34 & 126.72 & 140.73 & 144.51 & 3.44 & 0.154 \\
\hline Isoleucine & 200.15 & 227.27 & 203.17 & 206.78 & 212.50 & 5.90 & 0.623 \\
\hline Leucine & 272.47 & 305.75 & 255.92 & 261.08 & 252.83 & 7.08 & 0.126 \\
\hline Phenylalanine & 206.62 & 219.99 & 197.31 & 202.84 & 203.49 & 4.55 & 0.590 \\
\hline Valine & 368.39 & 402.46 & 347.66 & 370.04 & 365.57 & 8.80 & 0.400 \\
\hline Threonine & 131.98 & 174.13 & 138.68 & 140.79 & 160.39 & 8.79 & 0.537 \\
\hline Arginine & $407.26^{\mathrm{B}}$ & $471.80^{A B}$ & $540.05^{\mathrm{A}}$ & $528.63^{A}$ & $434.36^{\mathrm{AB}}$ & 15.44 & 0.037 \\
\hline \multicolumn{8}{|l|}{ Non-essential amino acid } \\
\hline Tyrosine & 156.28 & 177.26 & 152.29 & 166.32 & 187.46 & 5.92 & 0.314 \\
\hline Alanine & $648.46^{\mathrm{B}}$ & $781.34^{\mathrm{AB}}$ & $710.91^{B}$ & $710.52^{\mathrm{B}}$ & $860.09^{A}$ & 21.02 & 0.029 \\
\hline Aspartate & $100.80^{\mathrm{A}}$ & $102.90^{\mathrm{A}}$ & $91.02^{\mathrm{AB}}$ & $80.77^{\mathrm{B}}$ & $82.94^{\mathrm{B}}$ & 2.51 & 0.019 \\
\hline Glutamate & 734.33 & 747.36 & 586.50 & 639.88 & 820.27 & 29.13 & 0.101 \\
\hline Glycine & 810.43 & 773.85 & 811.29 & 758.24 & 875.34 & 30.42 & 0.773 \\
\hline Serine & 173.97 & 188.12 & 183.17 & 158.89 & 195.41 & 6.19 & 0.390 \\
\hline Cysteine & 93.28 & 119.84 & 101.66 & 105.77 & 109.84 & 2.94 & 0.082 \\
\hline Proline & $290.28^{B}$ & $370.19^{A}$ & $412.60^{A}$ & $400.86^{\mathrm{A}}$ & $453.46^{\mathrm{A}}$ & 12.43 & 0.003 \\
\hline \multicolumn{8}{|l|}{ Other AA } \\
\hline Taurine & 237.35 & 242.97 & 214.22 & 191.53 & 216.51 & 5.98 & 0.065 \\
\hline Urea & 1971.87 & 2219.22 & 1948.99 & 1891.50 & 1967.06 & 82.46 & 0.750 \\
\hline Sarcosine & $5.21^{\mathrm{B}}$ & $9.82^{\mathrm{B}}$ & $31.15^{\mathrm{A}}$ & $14.98^{\mathrm{B}}$ & $10.27^{\mathrm{B}}$ & 2.30 & 0.008 \\
\hline Citrulline & $132.51^{\mathrm{C}}$ & $161.98^{\mathrm{AB}}$ & $132.65^{\mathrm{C}}$ & $141.87^{\mathrm{BC}}$ & $170.41^{\mathrm{A}}$ & 4.01 & 0.009 \\
\hline Anserine & $20.60^{A}$ & $1.61^{\mathrm{B}}$ & $2.51^{\mathrm{B}}$ & $3.19^{B}$ & $1.80^{\mathrm{B}}$ & 1.83 & 0.008 \\
\hline Carnosine & $40.20^{\mathrm{B}}$ & $48.23^{\mathrm{B}}$ & $94.83^{\mathrm{A}}$ & $110.27^{\mathrm{A}}$ & $52.58^{\mathrm{B}}$ & 5.76 & 0.001 \\
\hline Cystathionine & 13.07 & 16.78 & 15.94 & 15.59 & 18.45 & 0.55 & 0.054 \\
\hline Hydroxylysine & 14.74 & 17.63 & 16.17 & 14.23 & 17.52 & 0.67 & 0.383 \\
\hline Ornithine & 118.98 & 136.44 & 118.74 & 117.85 & 140.36 & 5.55 & 0.537 \\
\hline a-Aminoadipic Acid & $118.00^{\mathrm{AB}}$ & $91.46^{\mathrm{B}}$ & $33.50^{C}$ & $49.56^{C}$ & $133.74^{\mathrm{A}}$ & 5.34 & $\varangle 0.0001$ \\
\hline a-Amino-n-butyric Acid & $12.61^{\mathrm{C}}$ & $20.14^{\mathrm{AB}}$ & $16.63^{\mathrm{BC}}$ & $17.72^{\mathrm{ABC}}$ & $23.40^{\mathrm{A}}$ & 0.94 & 0.012 \\
\hline$\beta$-Alanine & 37.47 & 33.59 & 36.23 & 36.23 & 35.88 & 1.82 & 0.975 \\
\hline$\beta$-Aminoisobutyric Acid & 3.49 & 6.82 & 6.70 & 8.78 & 7.22 & 0.57 & 0.085 \\
\hline Y-Aminobutyric Acid & $0.97^{\mathrm{B}}$ & $1.133^{\mathrm{B}}$ & $1.11^{\mathrm{B}}$ & $1.88^{\mathrm{A}}$ & $0.96^{\mathrm{B}}$ & 0.11 & 0.043 \\
\hline Ethanolamine & $10.25^{\mathrm{B}}$ & $12.49^{\mathrm{A}}$ & $9.16^{\mathrm{B}}$ & $9.32^{\mathrm{B}}$ & $9.18^{\mathrm{B}}$ & 0.23 & $\triangle 0.0001$ \\
\hline 1-Methylhistidine & 61.51 & 57.55 & 55.54 & 49.90 & 56.91 & 2.41 & 0.666 \\
\hline 3-Methylhistidine & 33.20 & 32.72 & 30.37 & 33.34 & 34.29 & 1.71 & 0.963 \\
\hline Hydroxy-L-proline & 181.21 & 156.19 & 137.98 & 132.13 & 142.29 & 6.13 & 0.112 \\
\hline Total & 167.40 & 181.49 & 161.25 & 157.77 & 168.82 & 4.86 & 0.586 \\
\hline
\end{tabular}


Table 3

Effects of dietary amylose/amylopectin ratio on organ weight in weaned piglets ${ }^{1}$.

\begin{tabular}{|c|c|c|c|c|c|c|c|c|c|c|c|c|c|c|}
\hline Items & 0.00 & & 0.20 & & 0.40 & & 0.60 & & 0.80 & & SEM & Pvalue & & \\
\hline & LPS & SAL & LPS & SAL & LPS & SAL & LPS & SAL & LPS & SAL & & $P_{D A R}$ & $P_{\text {stress }}$ & $P_{D * S}$ \\
\hline \multicolumn{15}{|l|}{ Absolute organ weight,g } \\
\hline Stomach & 81.4 & 74.8 & 91.4 & 77.2 & 77.6 & 77.3 & 84.1 & 74.3 & 81.0 & 79.1 & 1.70 & 0.737 & 0.061 & 0.692 \\
\hline Liver & 407.7 & 367.3 & 413.8 & 328.2 & 388.8 & 374.3 & 412.1 & 363.1 & 397.7 & 405.5 & 8.58 & 0.859 & 0.041 & 0.507 \\
\hline Spleen & 32.8 & 26.0 & 28.0 & 27.4 & 32.5 & 31.3 & 23.2 & 21.6 & 30.1 & 25.4 & 1.23 & 0.186 & 0.228 & 0.917 \\
\hline Kidney & 69.4 & 63.5 & 70.5 & 60.3 & 75.7 & 62.6 & 73.0 & 63.4 & 63.6 & 69.7 & 1.62 & 0.951 & 0.051 & 0.385 \\
\hline Small intestine, $\mathrm{kg}$ & 0.693 & 0.757 & 0.776 & 0.691 & 0.648 & 0.741 & 0.677 & 0.753 & 0.709 & 0.743 & 0.01 & 0.933 & 0.237 & 0.362 \\
\hline Large intestine, $\mathrm{kg}$ & 0.432 & 0.550 & 0.419 & 0.540 & 0.430 & 0.546 & 0.414 & 0.567 & 0.422 & 0.560 & 0.01 & 0.999 & 0.0001 & 0.989 \\
\hline \multicolumn{15}{|l|}{ Relative organ weight,g/kg } \\
\hline Stomach & 0.61 & 0.66 & 0.72 & 0.65 & 0.64 & 0.65 & 0.64 & 0.70 & 0.70 & 0.66 & 0.01 & 0.469 & 0.874 & 0.162 \\
\hline Liver & 3.06 & 3.26 & 3.23 & 2.77 & 3.16 & 3.21 & 3.11 & 3.45 & 3.48 & 3.29 & 0.05 & 0.174 & 0.890 & 0.098 \\
\hline Spleen & 0.25 & 0.23 & 0.22 & 0.23 & 0.27 & 0.26 & 0.17 & 0.20 & 0.27 & 0.21 & 0.01 & 0.162 & 0.701 & 0.713 \\
\hline Kidney & 0.52 & 0.57 & 0.55 & 0.51 & 0.62 & 0.52 & 0.54 & 0.61 & 0.57 & 0.55 & 0.01 & 0.557 & 0.639 & 0.121 \\
\hline Small intestine & 5.22 & 6.81 & 6.05 & 5.89 & 5.35 & 6.47 & 5.17 & 7.19 & 6.34 & 5.97 & 0.14 & 0.969 & 0.005 & 0.045 \\
\hline Large intestine & 3.29 & 4.83 & 3.26 & 4.59 & 3.53 & 4.73 & 3.10 & 5.32 & 3.50 & 4.54 & 0.09 & 0.894 & 0.0001 & 0.303 \\
\hline $\begin{array}{l}\text { Length of small intestine, } \\
\mathrm{m}\end{array}$ & 1.29 & 1.18 & 1.24 & 1.16 & 1.23 & 1.19 & 1.26 & 1.20 & 1.17 & 1.19 & 0.01 & 0.760 & 0.070 & 0.696 \\
\hline
\end{tabular}


Table 4

Effects of dietary amylose/amylopectin ratio and stress on serum biochemical index on day 29 in weaned piglets

\begin{tabular}{|c|c|c|c|c|c|c|c|c|c|c|c|c|c|}
\hline \multirow[t]{2}{*}{ Items } & \multicolumn{2}{|l|}{0.00} & \multicolumn{2}{|l|}{0.20} & \multicolumn{2}{|l|}{0.40} & \multicolumn{2}{|l|}{0.60} & \multicolumn{2}{|l|}{0.80} & \multirow[t]{2}{*}{ SEM } & \multicolumn{2}{|l|}{$P$ value } \\
\hline & LPS & SAL & LPS & SAL & LPS & SAL & LPS & SAL & LPS & SAL & & $P_{D A R}$ & $P_{\text {stress }}$ \\
\hline $\mathrm{TP}, \mathrm{g} / \mathrm{L}$ & 43.63 & 55.16 & 44.58 & 52.50 & 43.13 & 43.27 & 44.82 & 48.22 & 45.82 & 43.40 & 0.94 & 0.192 & 0.030 \\
\hline ALB, g/L & 23.72 & 21.46 & 21.92 & 25.22 & 21.68 & 21.35 & 25.65 & 23.98 & 23.33 & 22.60 & 0.60 & 0.483 & 0.774 \\
\hline ALT, U/L & 33.98 & 41.86 & 38.83 & 39.78 & 42.48 & 44.20 & 39.88 & 46.48 & 31.42 & 41.98 & 1.28 & 0.324 & 0.031 \\
\hline AST, U/L & 67.83 & 72.80 & 89.50 & 69.00 & 80.17 & 77.17 & 110.67 & 56.33 & 99.67 & 54.50 & 3.72 & 0.853 & 0.002 \\
\hline AST/ALT & 6.17 & 5.38 & 6.57 & 5.58 & 9.03 & 5.65 & 5.77 & 5.02 & 6.63 & 5.18 & 0.36 & 0.460 & 0.039 \\
\hline $\begin{array}{l}\text { BUN, } \\
\mathrm{mmol} / \mathrm{L}\end{array}$ & 91.33 & 57.20 & 96.33 & 63.83 & 87.50 & 64.83 & 107.00 & 60.33 & 100.67 & 61.83 & 2.26 & 0.670 & 0.000 \\
\hline $\begin{array}{l}\text { CREA, } \\
\text { umol/L }\end{array}$ & 4.43 & 4.90 & 4.17 & 5.23 & 3.83 & 5.22 & 3.88 & 4.97 & 3.37 & 5.33 & 0.12 & 0.869 & 0.000 \\
\hline $\begin{array}{l}\text { GLU, } \\
\mathrm{mmol} / \mathrm{L}\end{array}$ & 0.73 & 0.46 & 0.66 & 0.43 & 0.56 & 0.48 & 0.71 & 0.46 & 0.71 & 0.50 & 0.02 & 0.664 & 0.000 \\
\hline $\begin{array}{l}\mathrm{TG}, \\
\mathrm{mmol} / \mathrm{L}\end{array}$ & $2.14^{\mathrm{AB}}$ & 2.01 & $2.12^{A B}$ & 2.21 & $1.78^{\mathrm{B}}$ & 2.03 & $2.11^{\mathrm{A}}$ & 2.30 & $2.28^{\mathrm{A}}$ & 2.37 & 0.04 & 0.014 & 0.238 \\
\hline $\begin{array}{l}\mathrm{CHOL}, \\
\mathrm{mmol} / \mathrm{L}\end{array}$ & 2487.50 & 2248.80 & 2153.33 & 2454.67 & 1950.00 & 2429.50 & 2585.00 & 2370.33 & 2406.83 & 2593.50 & 81.08 & 0.712 & 0.519 \\
\hline $\begin{array}{l}\text { AMS, } \\
\text { U/L }\end{array}$ & $3.55^{\mathrm{C}}$ & 3.80 & $3.75^{\mathrm{BC}}$ & 4.63 & $4.30^{A B}$ & 5.22 & $4.58^{\mathrm{A}}$ & 6.02 & $4.15^{\mathrm{ABC}}$ & 4.65 & 0.16 & 0.027 & 0.014 \\
\hline $\begin{array}{l}\text { LIPC, } \\
\text { U/L }\end{array}$ & $3.55^{\mathrm{C}}$ & 3.80 & $3.75^{\mathrm{BC}}$ & 4.63 & $4.30^{\mathrm{AB}}$ & 5.22 & $4.58^{\mathrm{A}}$ & 6.02 & $4.15^{\mathrm{ABC}}$ & 4.65 & 0.16 & 0.027 & 0.014 \\
\hline$I G G, g / L$ & $0.37^{E}$ & 0.87 & $1.09^{D}$ & 6.99 & $5.57^{\mathrm{C}}$ & 7.52 & $6.74^{\mathrm{B}}$ & 17.19 & $16.41^{A}$ & 12.85 & 0.26 & 0.0001 & 0.0001 \\
\hline IGM,g/L & 0.66 & 0.85 & 0.51 & 0.51 & 0.54 & 0.55 & 0.47 & 0.77 & 0.68 & 0.54 & 0.03 & 0.146 & 0.259 \\
\hline
\end{tabular}

TP: total protein; ALB: albumin; ALT:alanine transaminase; AST: aspartate aminotransferase, BUN: blood urea nitrogen; CREA: creatinine; GLU: glucose; TG: triglyceride; CHOL: total cholesterol; AMS: amylase; LIPC: hepatic lipase; 
Table 5

Effects of dietary amylose/amylopectin ratio on serum free AA concentration on day 29 in weaned piglets

\begin{tabular}{|c|c|c|c|c|c|c|c|c|c|c|c|c|}
\hline Items & 0.00 & & 0.20 & & 0.40 & & 0.60 & & 0.80 & & SEM & $P$ value \\
\hline $\begin{array}{l}\text { Essential amino } \\
\text { acid }\end{array}$ & LPS & SAL & LPS & SAL & LPS & SAL & LPS & SAL & LPS & SAL & & $P_{\text {DAR }}$ \\
\hline Lysine & 290.83 & 461.73 & 299.34 & 439.69 & 344.25 & 383.30 & 289.37 & 517.96 & 362.64 & 529.83 & 14.10 & 0.332 \\
\hline Methionine & 88.53 & 109.98 & 71.44 & 145.46 & 80.73 & 101.33 & 67.04 & 168.53 & 63.65 & 148.75 & 3.99 & 0.290 \\
\hline Histidine & 111.83 & 114.56 & 111.21 & 124.90 & 129.58 & 116.57 & 97.37 & 126.11 & 118.01 & 128.32 & 3.08 & 0.662 \\
\hline Isoleucine & 189.06 & 241.42 & 148.19 & 298.79 & 172.41 & 234.18 & 148.91 & 281.43 & 130.05 & 280.38 & 6.91 & 0.883 \\
\hline Leucine & 209.84 & 248.70 & 186.51 & 270.96 & 222.90 & 213.75 & 180.88 & 240.34 & 179.25 & 247.79 & 5.85 & 0.789 \\
\hline Phenylalanine & 190.14 & 191.68 & 158.86 & 228.87 & 205.48 & 185.08 & 159.12 & 232.94 & 176.52 & 242.75 & 5.15 & 0.811 \\
\hline Valine & 321.02 & 375.51 & 292.89 & 450.46 & 350.52 & 357.90 & 279.32 & 407.13 & 273.61 & 427.02 & 9.16 & 0.886 \\
\hline Threonine & 88.26 & 93.72 & 85.80 & 126.89 & 96.80 & 96.43 & 86.83 & 121.27 & 83.86 & 122.10 & 3.80 & 0.715 \\
\hline Arginine & $328.56^{\mathrm{B}}$ & 365.26 & $300.14^{\mathrm{B}}$ & 430.07 & $310.30^{\mathrm{B}}$ & 417.24 & $275.51^{\mathrm{AB}}$ & 537.74 & $347.81^{\mathrm{A}}$ & 606.33 & 12.69 & 0.015 \\
\hline \multicolumn{13}{|l|}{$\begin{array}{l}\text { Non-essential } \\
\text { amino acid }\end{array}$} \\
\hline Tyrosine & 175.17 & 181.98 & 149.26 & 224.12 & 157.65 & 170.40 & 131.81 & 229.11 & 133.36 & 256.84 & 5.27 & 0.437 \\
\hline Alanine & 817.28 & 732.17 & 881.35 & 834.48 & 961.51 & 669.89 & 1219.58 & 817.30 & 903.89 & 703.50 & 27.71 & 0.060 \\
\hline Aspartate & 64.50 & 78.11 & 59.85 & 92.65 & 73.18 & 78.19 & 54.64 & 83.10 & 60.92 & 80.89 & 2.61 & 0.872 \\
\hline Glutamate & 616.87 & 639.59 & 526.48 & 793.71 & 584.36 & 642.12 & 495.57 & 735.61 & 553.77 & 661.64 & 23.35 & 0.955 \\
\hline Glycine & 785.89 & 620.18 & 722.03 & 948.18 & 874.09 & 789.05 & 1016.83 & 795.10 & 668.99 & 775.45 & 27.50 & 0.128 \\
\hline Serine & 169.54 & 137.75 & 150.71 & 207.84 & 179.11 & 156.57 & 206.91 & 180.88 & 150.52 & 165.47 & 4.97 & 0.089 \\
\hline Cysteine & 104.91 & 81.56 & 99.86 & 76.33 & 113.40 & 94.96 & 119.98 & 93.51 & 131.90 & 94.06 & 3.12 & 0.092 \\
\hline Proline & $287.69^{C}$ & 325.81 & $350.11^{A B}$ & 477.26 & $350.40^{\mathrm{BC}}$ & 355.05 & $411.45^{\mathrm{A}}$ & 503.95 & $333.15^{\mathrm{BC}}$ & 405.19 & 10.57 & 0.001 \\
\hline \multicolumn{13}{|l|}{ Other AA } \\
\hline Taurine & 170.19 & 207.61 & 169.97 & 192.20 & 181.97 & 162.60 & 156.89 & 163.98 & 172.31 & 186.49 & 4.70 & 0.405 \\
\hline Urea & 2985.70 & 2251.38 & 2747.70 & 2300.43 & 2445.53 & 2480.56 & 2459.77 & 2121.04 & 2912.18 & 2307.53 & 65.11 & 0.502 \\
\hline Sarcosine & $5.03^{C}$ & 6.57 & $23.50^{\mathrm{A}}$ & 27.01 & $14.50^{\mathrm{B}}$ & 14.04 & $31.95^{\mathrm{A}}$ & 34.50 & $29.80^{A}$ & 30.71 & 1.06 & 0.0001 \\
\hline Citrulline & $166.38^{\mathrm{B}}$ & 136.89 & $186.49^{\mathrm{AB}}$ & 164.00 & $190.54^{\mathrm{AB}}$ & 154.22 & $182.22^{\mathrm{AB}}$ & 174.65 & $221.01^{A}$ & 190.20 & 4.85 & 0.024 \\
\hline Anserine & $2.94^{\mathrm{BC}}$ & 2.37 & $0.52^{C}$ & 0.00 & $4.11^{\mathrm{ABC}}$ & 5.22 & $5.44^{\mathrm{AB}}$ & 7.60 & $11.54^{\mathrm{A}}$ & 7.16 & 0.73 & 0.003 \\
\hline Carnosine & 47.58 & 30.79 & 37.03 & 38.89 & 44.61 & 39.59 & 53.22 & 26.42 & 43.69 & 32.99 & 1.57 & 0.926 \\
\hline Cystathionine & 20.40 & 14.14 & 17.15 & 20.00 & 17.05 & 15.95 & 18.66 & 17.41 & 17.04 & 14.88 & 0.74 & 0.787 \\
\hline Hydroxylysine & $12.04^{\mathrm{B}}$ & 13.48 & $9.06^{\mathrm{B}}$ & 11.64 & $11.63^{\mathrm{B}}$ & 13.00 & $11.80^{\mathrm{B}}$ & 13.03 & $18.29^{A}$ & 18.69 & 0.67 & 0.005 \\
\hline Ornithine & $155.05^{\mathrm{B}}$ & 232.42 & $173.61^{A B}$ & 243.92 & $171.88^{\mathrm{B}}$ & 211.13 & $165.96^{\mathrm{AB}}$ & 256.64 & $197.85^{\mathrm{A}}$ & 276.09 & 5.67 & 0.100 \\
\hline $\begin{array}{l}\text { a-Aminoadipic } \\
\text { acid }\end{array}$ & 149.35 & 109.72 & 131.54 & 164.00 & 151.77 & 137.55 & 164.84 & 157.76 & 170.94 & 158.45 & 5.77 & 0.357 \\
\hline $\begin{array}{l}\text { a-Amino-n- } \\
\text { butyric acid }\end{array}$ & 16.66 & 21.25 & 17.80 & 27.98 & 17.62 & 17.92 & 12.13 & 24.97 & 14.23 & 26.31 & 1.06 & 0.582 \\
\hline$\beta$-Alanine & 57.39 & 31.15 & 34.28 & 30.19 & 41.16 & 26.63 & 45.87 & 39.06 & 53.16 & 35.74 & 1.89 & 0.115 \\
\hline $\begin{array}{l}\beta- \\
\text { Aminoisobutyric } \\
\text { acid }\end{array}$ & $5.80^{A}$ & 7.28 & $0.92^{\mathrm{B}}$ & 1.72 & $3.10^{\mathrm{B}}$ & 1.59 & $4.18^{\mathrm{A}}$ & 8.38 & $8.11^{\mathrm{A}}$ & 4.98 & 0.42 & 0.000 \\
\hline
\end{tabular}




\begin{tabular}{|lcccccccccccccc}
$\begin{array}{l}\text { Y-Aminobutyric } \\
\text { acid }\end{array}$ & 2.09 & 1.69 & 1.50 & 1.66 & 2.78 & 1.25 & 1.45 & 3.92 & 3.11 & 3.25 & 0.26 & 0.304 \\
\hline Ethanolamine & 9.86 & 10.81 & 10.18 & 9.17 & 10.02 & 7.62 & 10.76 & 9.66 & 13.45 & 9.24 & 0.40 & 0.368 \\
\hline $\begin{array}{l}\text { M- } \\
\text { Methylhistidine }\end{array}$ & 71.09 & 42.86 & 47.79 & 62.23 & 65.33 & 55.25 & 59.19 & 64.74 & 56.45 & 58.50 & 2.37 & 0.891 \\
\hline $\begin{array}{l}\text { 3- } \\
\text { Methylhistidine }\end{array}$ & 13.65 & 33.01 & 12.85 & 17.08 & 24.80 & 19.76 & 13.94 & 16.75 & 20.60 & 18.02 & 1.32 & 0.167 \\
\hline $\begin{array}{l}\text { Hydroxy-L- } \\
\text { proline }\end{array}$ & $161.69^{\mathrm{B}}$ & 85.02 & $155.94^{\mathrm{A}}$ & 161.40 & $153.41^{\mathrm{AB}}$ & 155.79 & $199.73^{\mathrm{A}}$ & 138.12 & $142.28^{\mathrm{AB}}$ & 146.45 & 4.20 & 0.019 \\
\hline
\end{tabular}


Table 6

Effects of dietary amylose/amylopectin ratio on amino acid composition in liver and muscle of weaned piglets ${ }^{1}$.

\begin{tabular}{|c|c|c|c|c|c|c|c|c|c|c|c|c|c|c|}
\hline Items & 0.00 & & 0.20 & & 0.40 & & 0.60 & & 0.80 & & SEM & $P$ valu & & \\
\hline $\begin{array}{l}\text { Longissimus } \\
\text { dorsi muscle }\end{array}$ & LPS & SAL & LPS & SAL & LPS & SAL & LPS & SAL & LPS & SAL & & $P_{\text {DAR }}$ & $P_{\text {stress }}$ & $P_{D * S}$ \\
\hline Lysine & 5.691 & 5.461 & 6.649 & 4.825 & 4.629 & 4.800 & 6.380 & 5.967 & 4.667 & 5.483 & 0.26 & 0.487 & 0.591 & 0.637 \\
\hline Methionine & 1.790 & 1.789 & 2.301 & 1.801 & 1.625 & 1.812 & 2.281 & 2.043 & 1.622 & 1.877 & 0.10 & 0.595 & 0.783 & 0.787 \\
\hline Histidine & 2.636 & 2.455 & 3.205 & 2.170 & 2.062 & 2.280 & 2.902 & 2.702 & 2.039 & 2.562 & 0.12 & 0.468 & 0.587 & 0.355 \\
\hline Isoleucine & 3.855 & 3.800 & 4.977 & 3.802 & 5.737 & 4.001 & 4.841 & 4.471 & 3.461 & 3.981 & 0.25 & 0.576 & 0.292 & 0.680 \\
\hline Leucine & 6.530 & 6.438 & 8.152 & 6.110 & 8.120 & 6.273 & 7.901 & 7.425 & 5.847 & 6.758 & 0.38 & 0.803 & 0.368 & 0.733 \\
\hline Phenylalanine & 1.885 & 1.853 & 2.221 & 1.727 & 2.437 & 1.701 & 2.253 & 2.056 & 1.587 & 1.852 & 0.11 & 0.776 & 0.301 & 0.676 \\
\hline Valine & 3.684 & 3.600 & 4.429 & 3.170 & 3.376 & 3.254 & 4.249 & 3.925 & 3.050 & 3.619 & 0.18 & 0.644 & 0.510 & 0.633 \\
\hline Threonine & 3.277 & 3.253 & 3.971 & 2.851 & 2.586 & 2.889 & 3.773 & 3.508 & 2.769 & 3.247 & 0.15 & 0.436 & 0.695 & 0.553 \\
\hline Arginine & 4.597 & 4.429 & 5.482 & 3.840 & 3.468 & 3.901 & 5.157 & 4.802 & 3.775 & 4.327 & 0.22 & 0.393 & 0.600 & 0.553 \\
\hline Aspartate & 6.728 & 6.574 & 8.131 & 5.771 & 5.233 & 5.889 & 7.707 & 7.200 & 5.646 & 6.616 & 0.32 & 0.421 & 0.673 & 0.536 \\
\hline Serine & 2.865 & 2.831 & 3.473 & 2.482 & 2.264 & 2.543 & 3.315 & 3.105 & 2.448 & 2.832 & 0.14 & 0.442 & 0.689 & 0.571 \\
\hline Glutamate & 11.438 & 11.209 & 13.592 & 9.858 & 8.955 & 9.982 & 13.060 & 12.207 & 9.613 & 11.213 & 0.54 & 0.442 & 0.696 & 0.596 \\
\hline Glycine & 3.792 & 3.368 & 4.663 & 3.034 & 3.108 & 3.330 & 4.263 & 4.082 & 3.251 & 3.307 & 0.19 & 0.520 & 0.327 & 0.601 \\
\hline Alanine & 4.797 & 4.566 & 5.633 & 3.985 & 3.821 & 4.092 & 5.419 & 5.057 & 3.972 & 4.568 & 0.23 & 0.484 & 0.564 & 0.621 \\
\hline Cysteine & - & - & - & - & - & - & - & - & - & - & & & & \\
\hline Tyrosine & 0.963 & 0.852 & 1.050 & 1.055 & 1.173 & 0.737 & 1.597 & 1.204 & 1.024 & 1.233 & 0.10 & 0.559 & 0.470 & 0.827 \\
\hline $\mathrm{NH} 3$ & 1.161 & 1.140 & 1.363 & 0.946 & 0.792 & 0.967 & 1.371 & 1.236 & 0.992 & 1.140 & 0.06 & 0.259 & 0.675 & 0.515 \\
\hline Proline & 3.337 & 2.978 & 4.139 & 2.698 & 2.568 & 2.877 & 3.762 & 3.677 & 2.853 & 3.006 & 0.16 & 0.369 & 0.402 & 0.500 \\
\hline \multicolumn{15}{|l|}{ Liver } \\
\hline Lysine & 3.205 & 2.605 & 2.791 & 2.972 & 3.110 & 2.528 & 3.183 & 2.327 & 2.879 & 2.425 & 0.05 & 0.526 & 0.0001 & 0.057 \\
\hline Methionine & 0.919 & 0.705 & 0.838 & 0.891 & 0.902 & 0.731 & 0.900 & 0.673 & 0.829 & 0.658 & 0.01 & 0.181 & 0.0001 & 0.083 \\
\hline Histidine & 1.074 & 0.901 & 0.975 & 1.036 & 1.046 & 0.877 & 1.031 & 0.822 & 0.951 & 0.839 & 0.01 & 0.133 & 0.0001 & 0.120 \\
\hline Isoleucine & 1.847 & 1.548 & 1.727 & 1.804 & 1.828 & 1.518 & 1.866 & 1.385 & 1.703 & 1.487 & 0.02 & 0.242 & 0.0001 & 0.034 \\
\hline Leucine & 3.865 & 3.238 & 3.575 & 3.790 & 3.878 & 3.229 & 3.917 & 3.004 & 3.640 & 3.174 & 0.05 & 0.562 & 0.0001 & 0.049 \\
\hline Phenylalanine & 2.048 & 1.763 & 1.902 & 2.038 & 2.060 & 1.713 & 2.046 & 1.570 & 1.902 & 1.612 & 0.03 & 0.148 & 0.0001 & 0.042 \\
\hline Valine & 2.366 & 2.018 & 2.213 & 2.310 & 2.326 & 1.912 & 2.360 & 1.784 & 2.157 & 1.871 & 0.03 & 0.129 & 0.0001 & 0.062 \\
\hline Threonine & 1.982 & 1.661 & 1.819 & 1.934 & 1.991 & 1.614 & 1.999 & 1.513 & 1.855 & 1.550 & 0.03 & 0.317 & 0.0001 & 0.031 \\
\hline Arginine & 2.777 & 2.299 & 2.574 & 2.678 & 2.784 & 2.223 & 2.807 & 2.055 & 2.596 & 2.149 & 0.04 & 0.320 & 0.0001 & 0.059 \\
\hline Aspartate & 4.000 & 3.367 & 3.694 & 3.880 & 4.039 & 3.291 & 4.048 & 3.085 & 3.763 & 3.182 & 0.05 & 0.414 & 0.0001 & 0.046 \\
\hline Serine & 2.110 & 1.790 & 1.927 & 2.058 & 2.103 & 1.729 & 2.120 & 1.611 & 1.963 & 1.660 & 0.03 & 0.311 & 0.0001 & 0.037 \\
\hline Glutamate & 6.118 & 5.148 & 5.659 & 5.870 & 6.211 & 5.061 & 6.190 & 4.754 & 5.792 & 4.887 & 0.07 & 0.419 & 0.0001 & 0.041 \\
\hline Glycine & 2.483 & 2.147 & 2.283 & 2.424 & 2.478 & 2.083 & 2.522 & 1.891 & 2.294 & 2.026 & 0.03 & 0.378 & , & 0.047 \\
\hline
\end{tabular}




\begin{tabular}{|c|c|c|c|c|c|c|c|c|c|c|c|c|c|c|}
\hline & & & & & & & & & & & & \multicolumn{3}{|c|}{0.0001} \\
\hline Alanine & 2.764 & 2.487 & 2.680 & 2.823 & 2.862 & 2.407 & 2.944 & 2.237 & 2.713 & 2.336 & 0.04 & 0.464 & $\begin{array}{l}0.0001 \\
0.07\end{array}$ & 0.056 \\
\hline Cysteine & $0.32^{\mathrm{A}}$ & 0.287 & $0.33^{\mathrm{A}}$ & 0.321 & $0.33^{\mathrm{AB}}$ & 0.223 & $0.36^{\mathrm{AB}}$ & 0.197 & $0.29^{\mathrm{B}}$ & 0.205 & 0.01 & 0.034 & $\begin{array}{l}\square \\
0.0001\end{array}$ & 0.126 \\
\hline Tyrosine & 1.391 & 1.106 & 1.346 & 1.467 & 1.527 & 1.253 & 1.513 & 1.159 & 1.451 & 1.172 & 0.02 & 0.265 & $\begin{array}{l}0.0001 \\
0.00\end{array}$ & 0.051 \\
\hline NH3 & 0.686 & 0.570 & 0.644 & 0.622 & 0.674 & 0.534 & 0.679 & 0.514 & 0.600 & 0.502 & 0.01 & 0.065 & $\begin{array}{l}\square \\
0.0001\end{array}$ & 0.406 \\
\hline Proline & 2.019 & 1.716 & 1.855 & 1.995 & 2.031 & 1.684 & 2.082 & 1.584 & 1.930 & 1.644 & 0.03 & 0.675 & $\begin{array}{l}0.0001 \\
0.00\end{array}$ & 0.052 \\
\hline
\end{tabular}

Table 7

Effects of dietary amylose/amylopectin ratio on antioxidant activity in liver and muscle of weaned piglets ${ }^{1}$.

\begin{tabular}{|c|c|c|c|c|c|c|c|c|c|c|c|c|c|}
\hline \multirow[t]{2}{*}{ Items } & \multicolumn{2}{|l|}{0.00} & \multicolumn{2}{|l|}{0.20} & \multicolumn{2}{|l|}{0.40} & \multicolumn{2}{|l|}{0.60} & \multicolumn{2}{|l|}{0.80} & \multirow[t]{2}{*}{ SEM } & \multicolumn{2}{|l|}{$P$ value } \\
\hline & LPS & SAL & LPS & SAL & LPS & SAL & LPS & SAL & LPS & SAL & & $P_{D A R}$ & $P_{\text {stress }}$ \\
\hline \multicolumn{14}{|l|}{$\begin{array}{l}\text { Enzymatic } \\
\text { activity }\end{array}$} \\
\hline \multicolumn{14}{|c|}{ Longissimus dorsi muscle } \\
\hline $\begin{array}{l}\text { T- } \\
\text { AOC,mmol/mg } \\
\text { pro }\end{array}$ & $19.80^{\mathrm{C}}$ & 17.97 & $31.0^{\mathrm{BC}}$ & 20.37 & $19.20^{\mathrm{B}}$ & 47.20 & $47.85^{\mathrm{A}}$ & 45.32 & $51.17^{\mathrm{A}}$ & 31.63 & 1.37 & 0.0001 & 0.651 \\
\hline $\begin{array}{l}\text { MDA,nmol/mg } \\
\text { pro }\end{array}$ & 0.12 & 0.09 & 0.07 & 0.16 & 0.21 & 0.43 & 0.10 & 0.18 & 0.17 & 0.23 & 0.04 & 0.305 & 0.250 \\
\hline \multicolumn{14}{|l|}{ Liver } \\
\hline $\begin{array}{l}\text { T- } \\
\text { AOC,mmol/mg } \\
\text { pro }\end{array}$ & 61.30 & 71.64 & 71.57 & 108.91 & 73.33 & 89.47 & 121.65 & 74.43 & 111.92 & 73.52 & 5.12 & 0.379 & 0.685 \\
\hline $\begin{array}{l}\mathrm{GSH}-\mathrm{PX}, \mathrm{U} / \mathrm{mg} \\
\text { pro }\end{array}$ & $1385^{\mathrm{AB}}$ & 576.11 & $1700^{\mathrm{A}}$ & 805.25 & $585.06^{C}$ & 187.56 & $468.24^{C}$ & 172.90 & $748.88^{\mathrm{BC}}$ & 422.90 & 73.75 & 0.001 & 0.001 \\
\hline $\begin{array}{l}\text { MDA,nmol/mg } \\
\text { pro }\end{array}$ & $0.83^{C}$ & 1.00 & $4.57^{\mathrm{A}}$ & 3.60 & $2.03^{B C}$ & 2.01 & $2.91^{\mathrm{AB}}$ & 3.39 & $1.69^{\mathrm{BC}}$ & 2.15 & 0.20 & 0.000 & 0.958 \\
\hline $\begin{array}{l}\text { T-SOD,U/mg } \\
\text { pro }\end{array}$ & $1102.68^{A}$ & 358.90 & $54.75^{\mathrm{C}}$ & 55.93 & $172.82^{\mathrm{BC}}$ & 347.69 & $527.17^{A B}$ & 513.93 & $401.35^{\mathrm{BC}}$ & 278.50 & 46.51 & 0.000 & 0.133 \\
\hline $\begin{array}{l}\text { Cu-SOD,U/mg } \\
\text { pro }\end{array}$ & $497.18^{\mathrm{A}}$ & 212.97 & $39.01^{\mathrm{B}}$ & 40.47 & $181.45^{\mathrm{A}}$ & 365.42 & $468.21^{\mathrm{A}}$ & 459.46 & $321.30^{\mathrm{A}}$ & 225.84 & 37.94 & 0.001 & 0.500 \\
\hline \multicolumn{14}{|l|}{$\begin{array}{l}\text { mRNA } \\
\text { expression in } \\
\text { liver }\end{array}$} \\
\hline SOD1 & $2.51^{\mathrm{A}}$ & 1.06 & $1.05^{\mathrm{B}}$ & 0.77 & $0.71^{\mathrm{B}}$ & 0.89 & $1.08^{\mathrm{B}}$ & 1.27 & $0.82^{\mathrm{B}}$ & 0.69 & 0.07 & 0.000 & 0.044 \\
\hline Nrf2 & $2.40^{\mathrm{A}}$ & 1.05 & $1.34^{\mathrm{B}}$ & 1.01 & $0.94^{\mathrm{B}}$ & 1.27 & $1.30^{\mathrm{AB}}$ & 1.37 & $0.83^{B}$ & 1.04 & 0.07 & 0.016 & 0.148 \\
\hline GPX1 & $2.95^{\mathrm{A}}$ & 1.10 & $1.73^{\mathrm{B}}$ & 0.50 & $0.92^{\mathrm{B}}$ & 0.64 & $1.27^{\mathrm{B}}$ & 1.05 & $1.48^{\mathrm{B}}$ & 0.67 & 0.10 & 0.006 & 0.000 \\
\hline GCLC & 1.80 & 1.05 & 1.11 & 0.82 & 1.04 & 1.45 & 1.03 & 2.02 & 0.90 & 1.23 & 0.08 & 0.167 & 0.396 \\
\hline
\end{tabular}

MDA: malonaldehyde; T-SOD: total superoxide dismutase; CuZnSOD: cooper-zinc; Mn-SOD: manganese SOD; GSH-PX: glutathione peroxidase; T-AOC: total ar capacity; GCLC: glutamate-cysteine ligase catalytic subunit; Nrf2: nuclear factor, erythroid 2 like 2; SOD1: superoxide dismutase; GPX1: and glutathione perox 
Table 8

Effects of dietary amylose/amylopectin ratio on mineral element concentrations in liver and muscle of weaned piglets ${ }^{1}$.

\begin{tabular}{|c|c|c|c|c|c|c|c|c|c|c|c|c|}
\hline Items,mg/g & 0.00 & & 0.20 & & 0.40 & & 0.60 & & 0.80 & & SEM & $P$ value \\
\hline TRET & LPS & SAL & LPS & SAL & LPS & SAL & LPS & SAL & LPS & SAL & & $P_{\text {DAR }}$ \\
\hline \multicolumn{13}{|c|}{ Longissimus dorsi muscle } \\
\hline $\mathrm{Ca}$ & 541.57 & 600.98 & 602.88 & 567.83 & 768.83 & 638.92 & 643.99 & 486.53 & 435.03 & 508.39 & 23.97 & 0.060 \\
\hline $\mathrm{Cu}$ & $24.78^{A}$ & 31.34 & $31.38^{\mathrm{A}}$ & 38.26 & $46.12^{\mathrm{A}}$ & 33.71 & $32.96^{\mathrm{A}}$ & 32.07 & $16.21^{\mathrm{B}}$ & 7.17 & 2.53 & 0.014 \\
\hline $\mathrm{Fe}$ & 785.50 & 996.63 & 594.41 & 5365.35 & 1122.98 & 1291.09 & 1171.42 & 656.81 & 444.76 & 91.47 & 308.17 & 0.089 \\
\hline $\mathrm{Mg}$ & 159.31 & 127.06 & 141.41 & 109.02 & 135.51 & 138.45 & 139.88 & 118.24 & 125.57 & 149.06 & 5.26 & 0.836 \\
\hline $\mathrm{Mn}$ & 11.24 & 9.72 & 3.76 & 22.78 & 13.38 & 10.61 & 7.21 & 10.03 & 4.71 & 1.36 & 1.10 & 0.052 \\
\hline$S$ & 6486.19 & 6789.44 & 5393.02 & 5427.91 & 7813.21 & 5840.90 & 6038.85 & 4916.15 & 5888.60 & 6008.67 & 253.02 & 0.266 \\
\hline $\mathrm{Zn}$ & $151.52^{A}$ & 189.55 & $126.15^{\mathrm{A}}$ & 216.93 & $248.71^{A}$ & 209.02 & $174.17^{\mathrm{A}}$ & 203.53 & $101.84^{\mathrm{B}}$ & 57.07 & 13.34 & 0.018 \\
\hline \multicolumn{13}{|l|}{ Liver } \\
\hline $\mathrm{Ca}$ & 886.14 & 548.05 & 757.36 & 444.94 & 501.06 & 808.66 & 676.50 & 433.16 & 523.10 & 438.81 & 38.16 & 0.379 \\
\hline $\mathrm{Cu}$ & $18.11^{C}$ & 7.47 & $9.10^{C}$ & 11.66 & $7.41^{\mathrm{C}}$ & 8.13 & $6.86^{\mathrm{B}}$ & 44.77 & $58.99^{\mathrm{A}}$ & 47.34 & 1.67 & 0.0001 \\
\hline $\mathrm{Fe}$ & $173.35^{\mathrm{B}}$ & 126.28 & $98.46^{\mathrm{B}}$ & 60.56 & $85.90^{\mathrm{B}}$ & 125.01 & $261.27^{A}$ & 12102.46 & $8588.29^{A}$ & 14655.24 & 863.02 & 0.000 \\
\hline $\mathrm{Mg}$ & 169.61 & 128.46 & 176.96 & 108.27 & 145.03 & 165.15 & 151.72 & 95.68 & 118.25 & 99.10 & 6.99 & 0.249 \\
\hline $\mathrm{Mn}$ & $6.59^{\mathrm{B}}$ & 1.29 & $1.66^{\mathrm{B}}$ & 1.22 & $1.35^{\mathrm{B}}$ & 1.95 & $5.98^{\mathrm{B}}$ & 43.89 & $31.97^{A}$ & 86.69 & 5.09 & 0.003 \\
\hline$S$ & 7964.21 & 5326.40 & 7390.98 & 3577.73 & 5095.49 & 5229.55 & 5351.62 & 5235.06 & 7050.15 & 5380.98 & 368.17 & 0.684 \\
\hline $\mathrm{Zn}$ & $147.72^{\mathrm{BC}}$ & 57.51 & $81.37^{C}$ & 79.64 & $63.50^{C}$ & 79.85 & $117.30^{\mathrm{B}}$ & 174.49 & $257.85^{A}$ & 241.75 & 7.84 & 0.0001 \\
\hline
\end{tabular}

Table 9

Effects of dietary amylose/amylopectin ratio on indole and skatole concentrations in cecal and colonic chyme of weaned piglets ${ }^{1}$.

\begin{tabular}{|c|c|c|c|c|c|c|c|c|c|c|c|c|c|c|}
\hline Items & 0.00 & & 0.20 & & 0.40 & & 0.60 & & 0.80 & & SEM & $P$ value & & \\
\hline Indol(e), $\mu \mathrm{g} / \mathrm{g}$ & LPS & SAL & LPS & SAL & LPS & SAL & LPS & SAL & LPS & SAL & & $P_{\text {DAR }}$ & $P_{\text {stress }}$ & $P_{D * S}$ \\
\hline Cecal chyme & $11.79^{\mathrm{A}}$ & 9.71 & $19.24^{\mathrm{AB}}$ & 3.62 & $9.84^{\mathrm{AB}}$ & 6.54 & $3.47^{\mathrm{AB}}$ & 2.86 & $0.00^{\mathrm{B}}$ & 4.07 & 1.01 & 0.031 & 0.123 & 0.091 \\
\hline Colonic chyme & 2.73 & 3.21 & 5.47 & 14.37 & 10.05 & 7.43 & 4.00 & 8.97 & 5.28 & 4.90 & 0.94 & 0.246 & 0.271 & 0.402 \\
\hline \multicolumn{15}{|l|}{ Skatole, $\mu \mathrm{g} / \mathrm{g}$} \\
\hline Cecal chyme & 11.01 & 8.93 & 23.64 & 13.57 & 20.69 & 6.59 & 14.17 & 5.44 & 0.35 & 8.78 & 1.46 & 0.102 & 0.108 & 0.214 \\
\hline Colonic chyme & $3.59^{C}$ & 8.18 & $8.81^{\mathrm{BC}}$ & 28.18 & $40.14^{\mathrm{AB}}$ & 23.62 & $30.56^{\mathrm{A}}$ & 44.94 & $39.81^{A B}$ & 15.88 & 2.20 & 0.002 & 0.930 & 0.019 \\
\hline
\end{tabular}

\section{Supplementary Files}

This is a list of supplementary files associated with this preprint. Click to download.

- SupplementaryTable.docx 